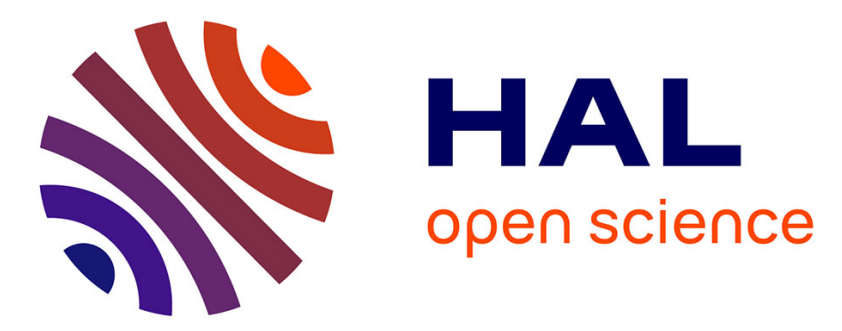

\title{
Instant one-pot preparation of functional layered double hydroxides (LDHs) via a continuous hydrothermal approach
}

\author{
Oana Pascu, Samuel Marre, Bastien Cacciuttolo, Ghina Ali, Laurence \\ Hecquet, Mathieu Pucheault, Vanessa Prevot, Cyril Aymonier
}

\section{To cite this version:}

Oana Pascu, Samuel Marre, Bastien Cacciuttolo, Ghina Ali, Laurence Hecquet, et al.. Instant one-pot preparation of functional layered double hydroxides (LDHs) via a continuous hydrothermal approach. ChemNanoMat, 2017, 3 (9), pp.614-619. 10.1002/cnma.201700125 . hal-01656067

\section{HAL Id: hal-01656067 https://hal.science/hal-01656067}

Submitted on 15 Jun 2021

HAL is a multi-disciplinary open access archive for the deposit and dissemination of scientific research documents, whether they are published or not. The documents may come from teaching and research institutions in France or abroad, or from public or private research centers.
L'archive ouverte pluridisciplinaire HAL, est destinée au dépôt et à la diffusion de documents scientifiques de niveau recherche, publiés ou non, émanant des établissements d'enseignement et de recherche français ou étrangers, des laboratoires publics ou privés. 


\title{
Instant One-Pot Preparation of Functional Layered Double Hydroxides (LDHs) via a Continuous Hydrothermal Approach
}

\author{
Oana Pascu, ${ }^{[a]}$ Samuel Marre, ${ }^{[a]}$ Bastien Cacciuttolo, ${ }^{[b]}$ Ghina Ali, ${ }^{[c]}$ Laurence Hecquet, $^{[c]}$ \\ Mathieu Pucheault, ${ }^{[b]}$ Vanessa Prevot, ${ }^{*[c]}$ and Cyril Aymonier ${ }^{*[a]}$
}

\begin{abstract}
Instant one-pot synthesis of functional layered double hydroxides (LDHs) is demonstrated for the first time using a continuous hydrothermal multi-step process. The as-prepared pristine material displays high crystallinity and very small LDH nanoparticle size, lateral dimensions below $100 \mathrm{~nm}$ and a thickness below $20 \mathrm{~nm}$, all being achieved in only $5 \mathrm{~s}$. This approach was extended to the preparation of i) pristine $\mathrm{LDH}$ with different compositions by varying the cation $(\mathrm{Mg}, \mathrm{Ni}$, or $\mathrm{Zn})$ and the anion $\left(\mathrm{CO}_{3}\right.$, $\mathrm{NO}_{3}$ ) and ii) functional $\mathrm{LDH}$ by varying the functionalization agent, for example long organic molecules (hybrid $L D H$ ), enzymes (bio-hybrid LDH) or inorganic metal/oxide nanocrystals (inorganic-LDH). Beyond the design of functional $\mathrm{LDH}$, this paper presents proof of concept for a continuous, one-pot and multistep high temperature/high pressure (HT/HP) process for the assembly of nanoscaled materials.
\end{abstract}

Synthetic layered double hydroxides (LDHs), commonly named hydrotalcite-like structures, belonging to the class of anionic clays, have been the subject of intense research since their first lab synthesis in 1942. ${ }^{[1 a]}$ The interest ${ }^{[1]}$ is based on their multiple applications: catalysis, ${ }^{[2]}$ sensing ${ }^{[1 \mathrm{c}, 3]}$ environment, ${ }^{[1 \mathrm{~b}, 4]}$ bio and pharmaceutics, ${ }^{[1 e, 5]}$ constructions, ${ }^{[6]}$ batteries, $^{[7]}$ stimuli responsive materials ${ }^{[8]}$ due to their attractive physicochemical properties arising from their structural and chemical features. In particular, the positively charged brucite-type $\left[\mathrm{Mg}(\mathrm{OH})_{2}\right]$ layers due to partial substitution of $\mathrm{M}^{2+}$ with $\mathrm{M}^{3+}$ ions $\left[\mathrm{M}_{1-x}{ }^{2+}\right.$ $\left.\mathrm{M}_{\mathrm{x}}^{3+}(\mathrm{OH})_{2}\right]$, stabilized by counter anions $\left(\mathrm{A}_{n}^{\mathrm{x} / n-}\right)$ within the in-

[a] Dr. O. Pascu, Dr. S. Marre, Dr. C. Aymonier

Supercritical Fluids group

CNRS, Univ. Bordeaux, ICMCB, UPR 9048

F-33600 Pessac (France)

E-mail: cyril.aymonier@icmcb.cnrs.fr

[b] Dr. B. Cacciuttolo, Dr. M. Pucheault

CNRS, Univ. Bordeaux, ISM, UMR 5255

F-33405 Talence (France)

[c] Dr. G. Ali, Prof. L. Hecquet, Dr. V. Prevot

Université Clermont Auvergne, CNRS, SIGMA Clermont, ICCF

F-63000 Clermont-Ferrand (France)

E-mail:vanessa.prevot@univ-bpclermont.fr terlayer space, are of high interest. The ability to manipulate and control the surface or properties of host LDH opens a myriad of design possibilities as multifunctional hybrid layered materials. For instance, by depositing Au nanoparticles of 2 $3 \mathrm{~nm}$ on a LDH-modified surface, the protein (e.g., hemoglobin) adsorption capacity of LDH was enhanced, ${ }^{[5 \mathrm{e}]}$ due to the covalent link formed between Au and the protein's free thiol (SH) groups.

Yet, the preparation of pristine or functional LDH is still limited to a few methods, with co-precipitation, anion exchange, reconstruction, alcohol/polyol or the urea method being the most used. ${ }^{[1 c, 4,5 b-d, 9]}$ These classical methods are convenient to demonstrate proof of concept of LDH preparation and optimization methods with control over the particle size, structure, morphology, chemical composition and crystallinity. However, their long processing times (from a few hours to days) are still limiting the process optimization, while generally leading to large crystal size (micrometer range). On the other hand, shorter residence times can achieve the right structure but with a loss in material crystallinity and homogeneity as observed for pristine LDH synthesis. ${ }^{[9]}$ Additionally, when functional hybrid LDH synthesis is targeted, several processing steps are mandatory for producing the desired material. ${ }^{[1,2 d-e, 5 b-d, 8,9 b, d, 10]}$ Applications using LDHs generally required advanced control over the platelets diameter (lateral dimension) and thickness (number of stuck layers). For instance, LDH basicity, anion exchange, adsorption properties or catalytic activity are enhanced by decreasing the LDH particles lateral size/ thickness down to the nanometer range. ${ }^{[1,9 c, e]}$ Unfortunately, the preparation of aqueous colloidal suspension of LDH with particle size below $100 \mathrm{~nm}$ is still challenging, ${ }^{[9 f-1]}$ although smaller LDH particles production was reported through alcohol-based routes. ${ }^{[9, c, j]}$ One way to decrease the particle size, while keeping the same LDH crystals properties, is to separate the nucleation of $\mathrm{LDH}$ particles and ageing/growth steps. ${ }^{[9]}$ This could be achieved by considering continuous precipitation methods, still scarcely studied so far. The first example was reported in 2006 with an in line dispersion-precipitation method to produce pristine $\mathrm{LDH}^{\left[{ }^{[11 a]}\right.}$ This was achieved using a microreactor equipped with in line $\mathrm{pH}$ control. Since then, Q. Wang et al. ${ }^{[11 \mathrm{~b}]}$ reported the use of a flow nozzle reactor in which the precipitation of LDH is taking place when two opposite flows, one being a base aqueous solution and the other a metal precursor solution (with controlled flow rate), are mixing. By varying the reaction temperature $\left(75-400^{\circ} \mathrm{C}\right.$ ) and pressure (5-24 MPa), 
$\mathrm{Mg}_{2} \mathrm{Al}-\mathrm{CO}_{3}$ and $\mathrm{Ca}_{2} \mathrm{Al}-\mathrm{NO}_{3} \mathrm{LDHs}$ up to $100 \mathrm{~nm}$ are formed with the disadvantage that $\mathrm{CaAl}$ and $\mathrm{MgAl} \mathrm{LDH}$ s above the reaction temperature of $150^{\circ} \mathrm{C}$ and $250^{\circ} \mathrm{C}$, respectively, start to decompose into $\mathrm{AlOOH} / \mathrm{Al}(\mathrm{OH})_{3}$ impurities. ${ }^{[11 \mathrm{~b}]}$ Recently, $\mathrm{H}$. Liang et al. ${ }^{[11 c]}$ reported the direct formation of pristine crystalline CoNi LDH nano-platelets (of $15 \mathrm{~nm}$ thickness and more than $100 \mathrm{~nm}$ in lateral dimension) perpendicular to the carbon support by pumping the mixture of metal salt precursors solutions into a continuous singular tubular reactor at $160^{\circ} \mathrm{C}$ and 1.1 $\mathrm{MPa}$ pressure during $4 \mathrm{~h}$. In this study we are reporting a step forward in the preparation of functional LDH materials. By introducing a new configured set-up, we are demonstrating the first instant one-pot synthesis of multifunctional LDH particles using a continuous co-flow hydrothermal precipitation approach (residence time $R_{\mathrm{t}}$ of $5 \mathrm{~s}, 175<T\left({ }^{\circ} \mathrm{C}\right)<200$, pressure of $20 \mathrm{MPa})$.

This novel approach (Figure 1) is validated by preparing: 1) small pristine $L D H$ particles (below $100 \mathrm{~nm}$ in lateral dimensions and $20 \mathrm{~nm}$ for the thickness); 2) hybrid LDH materials by in situ intercalation of large organic molecules, for example, DS (dodecyl sulfate); 3) bio-hybrid LDH with in situ enzymes immobilization (i.e., transketolase-TK) and 4) inorganic $L D H$ supported active nanocrystals $(P d, R u)$ by in situ formation and deposition of metal/oxide nanocrystals over LDH platelets whose catalytic activity in hydrogenation of cinnamaldehyde was further tested.

We have developed a continuous, high-pressure, co-flow ${ }^{[12 a]}$ system whose versatility has already been demonstrated for the preparation of different active hybrid nanocrystals, namely $\mathrm{ZnO}^{[12 \mathrm{~b}-\mathrm{c}]}$ and $\mathrm{Pd}^{[12 \mathrm{~d}-\mathrm{e}]} \mathrm{NPs}$. First, pristine $\mathrm{LDH}$ with different compositions $\mathrm{Mg}^{2+}, \mathrm{Ni}^{2+}$ or $\mathrm{Zn}^{2+}$ as $\mathrm{M}^{2+}, \mathrm{Al}^{3+}$ as $\mathrm{M}^{3+}$ in the molar ratio of 2 to 1 and $\mathrm{CO}_{3}{ }^{2-}$, as interlayered anion were prepared (Figure S1 and Table S1 in the Supporting Information), in order to access fundamental understanding of the precipitation mechanism but also to get some reference materials for

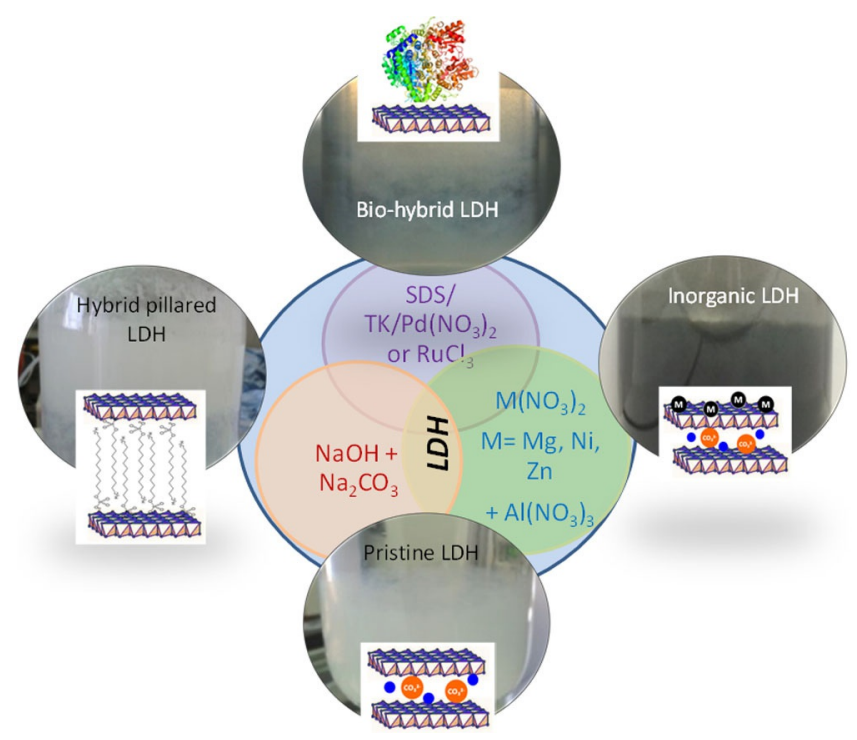

Figure 1. Sketch of the one-pot multistep process developed for the preparation of functional LDH materials. further comparison with the functional LDHs. A few attempts were made for the preparation of pristine LDH containing $\mathrm{NO}_{3}{ }^{-}$as interlayered anions, but further optimization of preparation procedure is needed. Then, keeping the experimental parameters constant, functional LDHs were synthesized by adding the functionalization agents (DS, TK, Pd or Ru salts precursors) to the LDH precursors (see Experimental Section and Table S1). The as-prepared LDH materials yield to fine precipitates, whose color varied depending on the functionalization agent (Figure 1).

Herein, we purposefully focused the discussion on the most common $\mathrm{CO}_{3}-\mathrm{LDH}$ type material, the pristine $\mathrm{CO}_{3}-\mathrm{LDH}$ namely, $\mathrm{Mg}_{2} \mathrm{Al}-\mathrm{CO}_{3}, \mathrm{Ni}_{2} \mathrm{Al}-\mathrm{CO}_{3}$ and $\mathrm{Zn}_{2} \mathrm{Al}-\mathrm{CO}_{3}$, labelled as Mg.C, Ni.C and $Z n . C$, respectively, are identified from XRD powder diffraction patterns, presented in Figure $2 \mathrm{a}$. The visible peaks can be indexed with standard JCPDS. ${ }^{[13 a]}$ For theoretical $\mathrm{M}^{\text {II }} / \mathrm{M}^{\mathrm{III}}$ ratio
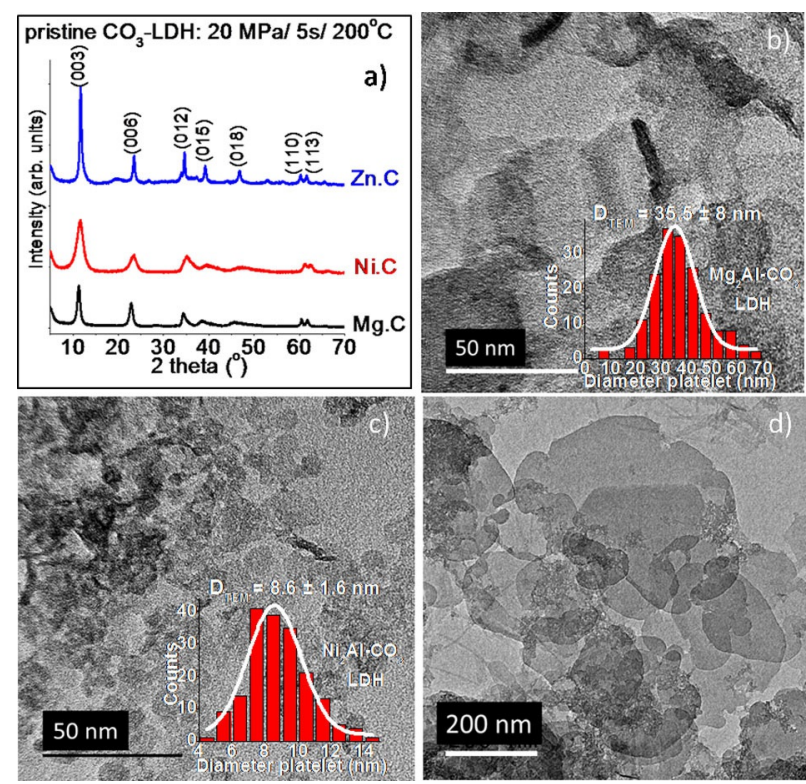

Figure 2. Structure and morphology of pristine LDH. (a) XRD pattern of $\mathrm{Mg}_{2} \mathrm{Al}-\mathrm{CO}_{3}, \mathrm{Ni}_{2} \mathrm{Al}-\mathrm{CO}_{3}$ and $\mathrm{Zn}_{2} \mathrm{Al}-\mathrm{CO}_{3}$ obtained at $20 \mathrm{MPa}$ pressure, $200^{\circ} \mathrm{C}$ and $5 \mathrm{~s}$ and TEM images of $\mathrm{Mg}_{2} \mathrm{Al}-\mathrm{CO}_{3}$ (b), Ni $\mathrm{Al}_{2}-\mathrm{CO}_{3}$ (c) and $\mathrm{Zn}_{2} \mathrm{Al}-\mathrm{CO}_{3}$ (d) $\mathrm{LDH}$ particles; Gaussian size distribution shown in inset (b and $c$ ).

equal to two, the $\mathrm{Mg} / \mathrm{Al}$ combination gives a unit cell a of $3.057 \AA$ and $c$ of $23.502 \AA$, while Ni/Al one gives $a=3.025 \AA$ and $c=22.59 \AA$. The $(003)$ peak appears at $2 \theta \approx 11.5^{\circ}$ evidencing an interlayer distance of $7.7 \AA( \pm 0.15)$, for all samples, in good agreement with the $\mathrm{CO}_{3}-\mathrm{LDH}$ obtained by classical precipitation method. ${ }^{[13 \mathrm{~b}]}$ Moreover, a difference in the (003) peak broadening can be clearly seen, attributed to a coherent domain size variation.

LDH structural and morphological information can be obtained from the analysis of (003) and (110) peaks of diffraction patterns: basal distance $\left(d_{003}=\right.$ thickness of brucite layer + interlayer space), cell parameters $\left(a=2 d_{110}\right.$ and $\left.c=3 d_{003}\right)$. Comparing the experimental " $a$ " and " $c$ " parameters with the standard ones, small deviations are observed. This could be attributed to the experimental $M^{\prime \prime} / M^{\prime \prime \prime}$ ratio different from the theo- 
retical one equal to two, investigated by ICP chemical analysis (see Supporting Information, Table S3). The crystal sizes for platelet-like shape, namely the lateral dimension (diameter), is given by $L_{110}$ while the thickness by $L_{003}$, and the corresponding numbers of layers stacked within one LDH particles. ${ }^{[9 d]} d_{003}$ and $d_{110}$ were calculated using the Bragg law, while $L_{003}$ and $L_{110}$ with the Scherrer equation (Table 1). The clear (110) and (113)

\begin{tabular}{|c|c|c|c|c|c|c|c|}
\hline Material & $\begin{array}{l}d_{003} \\
[\AA]]\end{array}$ & $\begin{array}{l}c \\
[\AA]]\end{array}$ & $\begin{array}{l}d_{110} \\
{[\AA]}\end{array}$ & $\begin{array}{l}a \\
[\AA]]\end{array}$ & $\begin{array}{l}L_{003} \\
[\AA]]\end{array}$ & $\begin{array}{l}L_{110} \\
{[\AA]}\end{array}$ & $\begin{array}{l}\text { Stacked } \\
\text { layers }\end{array}$ \\
\hline \multicolumn{8}{|c|}{ Pristine LDH } \\
\hline$M g . C^{[b]}$ & 7.82 & 23.46 & 1.53 & 3.062 & 115 & 230 & 15 \\
\hline $\mathrm{Ni} \cdot \mathrm{C}^{[\mathrm{b}]}$ & 7.61 & 22.83 & 1.51 & 3.013 & 56 & 100 & 7 \\
\hline $\mathrm{Zn} \cdot \mathrm{C}^{[\mathrm{b}]}$ & 7.56 & 22.69 & 1.54 & 3.077 & 175 & 230 & 23 \\
\hline$M g . C^{[c]}$ & 7.87 & 23.60 & 1.52 & 3.048 & 62 & - & 8 \\
\hline \multicolumn{8}{|c|}{ Functional LDH } \\
\hline Mg.C-DS & 27.01 & 81.03 & 1.52 & 3.036 & 131 & 84 & 5 \\
\hline Ni.C-DS & 28.73 & 86.19 & 1.51 & 3.014 & - & 61 & 4 \\
\hline Mg.C-Pd & 7.64 & 22.86 & 1.52 & 3.042 & 99.3 & 125 & 13 \\
\hline Mg.C-Ru & 7.66 & 22.95 & 1.52 & 3.041 & 96.4 & 193 & 13 \\
\hline Ni.C-Ru & 7.52 & 22.56 & 1.49 & 2.972 & 54.1 & - & 7 \\
\hline Mg.C-TK & 7.98 & 23.94 & 1.52 & 3.033 & 55.5 & - & 7 \\
\hline
\end{tabular}

[a] Number of layers per one LDH particle $=L_{003} / d_{003}$; [b] synthesis performed at $200^{\circ} \mathrm{C}$; [c] synthesis performed at $50^{\circ} \mathrm{C}$.

peaks reveal a good dispersion of metal ions in the hydroxide layers. ${ }^{[13 b]}$ Using the same experimental conditions, but playing with the type of LDH cations, different behaviors were found. The unit cell given by the " $a$ " parameter was found to be the highest for ZnAl, then MgAl and the smallest for NiAl. It is not very clear if the coherent domain size is mainly linked to the radii of the elements, namely $\mathrm{Mg}^{2+}, \mathrm{Ni}^{2+}, \mathrm{Zn}^{2+}$ and $\mathrm{Al}^{3+}$ with $72,70,74$ and 53 pm, respectively. ${ }^{[13]}$ The LDH nanoplatelets diameter $\left(L_{110}\right)$ and thickness $\left(L_{003}\right)$ are also different, increasing from NiAl to MgAl and $\mathrm{ZnAl}$, as observed by classical direct coprecipitation. This tendency was confirmed by LDH TEM images (Figure $2 \mathrm{~b}-\mathrm{d}$ ). Platelets-like rounded shapes were observed in all cases. In the case of Ni.C, the determined diameters from XRD and TEM analyses were 10 and $9 \mathrm{~nm}$, respectively, demonstrating the monocrystallinity of the $\mathrm{LDH}$ particles and a limited crystal growth in our conditions. Switching to Mg.C, a slight difference was found between the XRD calculated diameter and TEM measured sizes, ( $23 \mathrm{~nm}-\mathrm{XRD}$ and $36 \mathrm{~nm}$ -TEM), suggesting polycrystalline LDH nanoparticles. In the case of Zn.C, even further growth of crystals takes place with less-defined platelets shape.

The very large difference between the XRD ( $23 \mathrm{~nm})$ and TEM (around $200 \mathrm{~nm}$ ) size might be translated through the presence of several coherent domains in the same platelets with various orientations ${ }^{[14]}$ This behavior could be interpreted with a very imperfect $L D H$ where the array of atoms on the surface is disordered with crystal surface defects. ${ }^{[14]}$ This situation could happen in the case of a very fast ageing, typical of the considered synthesis conditions $\left(R_{\mathrm{t}}=5 \mathrm{~s}\right)$.
Functional LDHs were then prepared considering the same experimental parameters as for pristine, adding additionally the functionalization reagents in the precursor solution. Our continuous set-up demonstrated itself to be flexible in controlling the nucleation and functionalizing step, certifying its high versatility for preparing instant one-pot functional LDHs. In addition, small (from 8.6 to $200 \mathrm{~nm}$ depending on the considered metal cation-see Table $1-L_{003}, L_{110}$ and number of layers), pristine or functional LDH could be prepared. This configuration thus exhibits advantages over conventional batch approaches. The structure and morphology of the as-prepared functional $\mathrm{CO}_{3}-\mathrm{LDH}$ are presented in Figure 3, Figure 4 and Figure 5 , respectively.

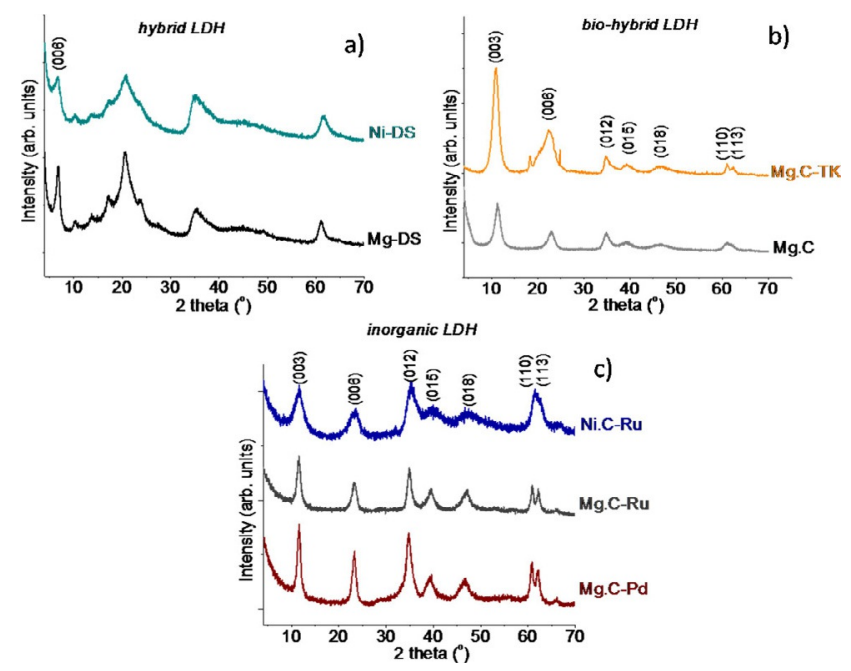

Figure 3. XRD diffraction patterns of functionalized LDH: (a) hybrid $L D H$ as Mg-DS and Ni-DS; (b) bio-hybrid LDH as Mg.C-TK (TK=transketolase) synthesis at $20 \mathrm{MPa}$ pressure, $50^{\circ} \mathrm{C}$ and $5 \mathrm{~s}$, compared to $\mathrm{Mg} . \mathrm{C}$ obtained at $20 \mathrm{MPa}$ pressure, $50^{\circ} \mathrm{C}$ and $5 \mathrm{~s}$ and (c) inorganic LDH as Mg.C-Pd, Mg.C-Ru (Pd and $\mathrm{Ru}$ in the form of nanocrystals) both types synthesized at $175-200^{\circ} \mathrm{C} /$ $20 \mathrm{MPa} / 5 \mathrm{~s}$.

XRD diffraction patterns are presented in Figure 3. LDH fully intercalated with dodecyl sulfate (DS), named hybrid LDH, labelled as Mg-DS and Ni-DS display the first peak at $2 \theta=6^{\circ}$ and all the expected harmonic diffraction lines (Figure $3 \mathrm{a}$ ), corresponding to a basal distance of $27 \AA$, as previously reported. ${ }^{[9 d]}$ For these hybrid LDHs, the estimated interlayer distance (Table 1) for both materials suggested an interdigitated bilayer arrangement of anionic surfactant (dodecyl sulfate) within the interlayer (Figure $3 \mathrm{a}$ ). ${ }^{[\mathrm{dd}]}$ The DS presence within the LDH structures was also confirmed by FTIR spectroscopy (Figure S4) and TGA measurements (Figure S5). A higher weight loss for the LDH-DS compared with the pristine LDH was observed, as expected and in agreement with a typical LDH behavior. ${ }^{[17]}$ As presented, there are not significant structural changes between pristine and functional LDH (according to XRD structural data), their lateral dimensions get smaller but their thickness remained similar. Rather an influence on LDH morphology of functional agents can be clearly observed (Figure 4). The hybrid LDH, endowed with hydrophobic characteristics, due to 

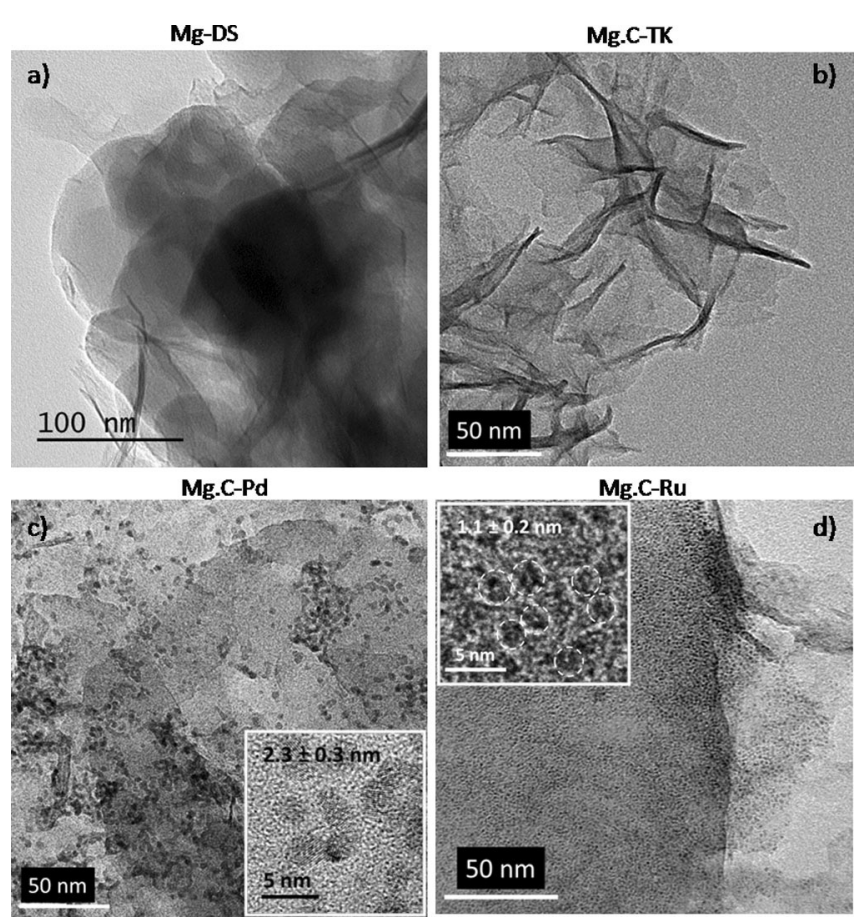

Figure 4. TEM images of functional LDH materials using: dodecyl sulfate DS (a), enzyme TK (b) and Pd (c) and Ru (d) NPs as functional agents.
Ni-DS

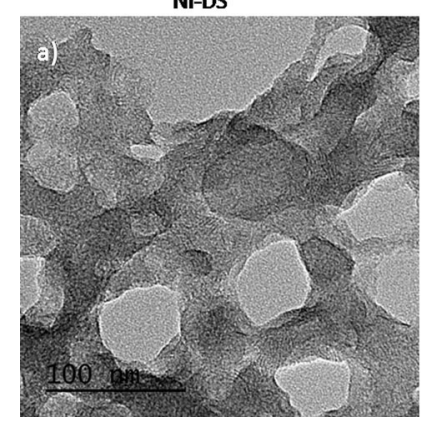

Ni.C-Ru

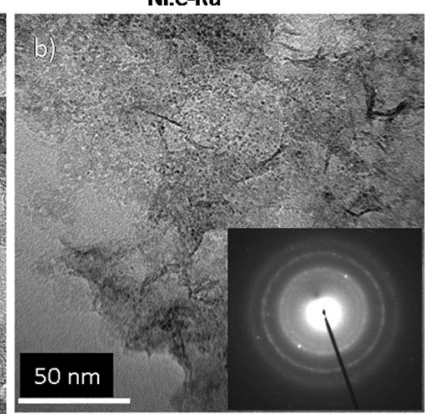

Figure 5. TEM images of functional $\mathrm{Ni}_{2} \mathrm{Al} \mathrm{LDH}$ materials with dodecyl sulfate DS (a), Ru NPs (b).

long carbon chain of dodecyl sulfate surfactant, present sticky morphologies (Figure $4 \mathrm{a}$ and S2a), in agreement with the one observed with classical synthetic routes. ${ }^{[9 d]}$ DS functional Nibased LDH materials are presented in Figure 5. To our surprise, their morphology is different than of the corresponding Mg.C; the Ni-based LDH seems to form more rounded shaped pellets within an organic network composed of the surfactant molecules. Further research is needed to fully understand this hybrid system morphology.

Bio-hybrid LDH (Mg.C-TK): In order to assess the ability of our process to immobilize enzymes on LDHs for the development of bioreactors and further applications in biocatalysis, thermostable Transketolase from Geobacillus stearothermophilus (TK ${ }^{[15 a]}$ belonging to the family of transferases was chosen as a model. This enzyme catalyzes a stereospecific carboligation reaction and its robustness allows using it in unusual media $^{[15 c]}$ or at elevated temperature ${ }^{[15 a, d]}$ for the synthesis of chiral polyols of biological interests.

Changing the long organic surfactant with a large enzyme $(\approx 9 \mathrm{~nm})$ in the synthetic process, ${ }^{[16 \mathrm{~b}]}$ the XRD pattern showed similar diffraction patterns compared to the reference (Mg.C$50^{\circ} \mathrm{C}$ ), exhibiting only slightly broader peaks (Figure $3 \mathrm{~b}$ ). The large enzyme size hampers its intercalation in between the layers. This indicates that the enzyme TK did not affect very much the LDH formation and crystallinity, although LDH amorphization with strong decrease in the coherent domain size was found when using classical method. ${ }^{[15 b]}$ Layered structure is still preserved but pellets aggregation is observed (Figure $4 \mathrm{~b}$ and $52 \mathrm{~b}$ ) since crystal growth occurs in the presence of TK proteins. ${ }^{[15 c, 17]}$ The presence of characteristic amide vibration bands of the enzyme on FTIR spectrum (Figure S4) further confirmed the successful immobilization on the inorganic layered matrix. It was reported ${ }^{[11 a]}$ that in continuous mode, LDH precipitates very fast (typically less than $1 \mathrm{~s}$ ). Based on this consideration, purified TK was pumped into the reactor (with a third high pressure pump) $2.5 \mathrm{~s}$ downstream the initial mixing point where LDH starts forming. The fast mixing in such configuration in the turbulent regime ensures that the reaction media has a pH higher than 7, optimal for TK adsorption. ${ }^{[1 c, 15 c, 17]}$ Indeed the critical factors in the enzyme immobilization are the immobilization yield and the preservation of the catalytic activity under process conditions. By analyzing the supernatant, an immobilization yield of $96 \%$ is calculated, evidencing the efficiency of our direct synthetic approach to immobilize biomolecules on inorganic support. The TK catalytic activity is determined using L-erythrulose as donor and Dribose 5-phosphate as acceptor and highlights that TK maintains at least half of its activity once immobilized on LDH. We assume that temperature and pressure used in our process slightly affect the enzyme and could be further optimized.

Inorganic LDH: It was reported ${ }^{[16]}$ that $M^{\text {II }}$ or $M^{\text {III }}$ with ionic radius close to the one of $\mathrm{Mg}^{2+}$ might be accommodated inside the brucite layers (isomorphic substitution of $\mathrm{Mg}^{2+}$ ), affecting the layer charge, the metal-metal distance and implicitly the amount of counter anions intercalated. This leads to a modification of the basal distance and of the physico-chemical properties. By functionalizing Mg.C LDH with $\mathrm{Pd}$ (using $\mathrm{Pd}\left(\mathrm{NO}_{3}\right)_{2}$ precursor), an isomorphic substitution of $\mathrm{Mg}^{2+}$ does not take place $\left(\mathrm{Pd}^{2+}\right.$ ionic radius is larger, $86 \mathrm{pm}$, than $\mathrm{Mg}^{2+}$ radius), but instead $\mathrm{Pd}$ nanocrystals are formed on the $\mathrm{LDH}$ platelet surface (Figure 1), certified also by TEM images (Figure $4 \mathrm{c}$ ). Similar behavior was observed for LDH formed in the presence of Ru precursor $\left(\mathrm{RuCl}_{3}\right)$, labelled Mg.C-Ru (Figure $4 \mathrm{~d}$ ), although $\mathrm{Ru}^{3+}$ is smaller than $\mathrm{Mg}^{2+}$, with a radius of $68 \mathrm{pm}$. For both metals, the formation of nanocrystals on LDH surface without modification of the LDH structure is confirmed by similar basal distances and cell parameters compared with pristine LDH (Table 1 and Figure 3c). The similar structural parameters found for both Mg.C-Pd (using a nitrate precursor) and Mg.C$\mathrm{Ru}$ (using a chloride precursor) demonstrate that the counter ion exchange $\mathrm{CO}_{3}{ }^{2-}$, by either $\mathrm{NO}_{3}{ }^{-}$and $\mathrm{Cl}^{-}$does not occur, which was confirmed by EDS measurements (Figure S6). This is in good agreement with LDH strong affinity for carbonate 
anions. ${ }^{[1]}$ Switching from $\mathrm{Mg}^{2+}$ to $\mathrm{Ni}^{2+}$, the addition of $\mathrm{Ru}^{3+}$ results in a different behavior (Table 1-label Ni.C-Ru). Indeed, a decrease of the basal $\left(d_{003}\right)$ and metal-metal $(a)$ distance can be noticed. This might be attributed to a partial substitution of $\mathrm{Ni}^{2+}$ by $\mathrm{Ru}^{3+}$, leading to an increase of layer positive charges and the electrostatic attraction followed by a decrease of the basal distance and the " $a$ " parameter.

The addition of $\mathrm{Pd}\left(\mathrm{NO}_{3}\right)_{2}$ to the $\mathrm{LDH}$ precursor leads to the formation of small Pd NCs ( $\approx 2 \mathrm{~nm}$ size) on the LDH surface (Figure 4c). Their high crystallinity was certified by HRTEM image (Figures $4 \mathrm{c}$-inset and S3) and the measured lattice fringes give a mean value of $0.194 \mathrm{~nm}$ (Table S3), corresponding to the (200) crystalline plane distance of Pd (JCPDS 46-1043). ${ }^{[18]}$ Note that when Ru precursor was used, a different LDH morphology was obtained. LDH pellets are not well defined but their morphology could be imagined as overlapping platelets areas decorated with very small $(\approx 1 \mathrm{~nm})$ NCs (Figure $4 \mathrm{~d}$ inset). Unfortunately, their crystalline nature by the presence of NCs lattice fringes was difficult to be revealed by HRTEM analysis, but the collected surface area electron diffraction (SAED) of Mg.C-Ru sample (Figure S2 d) showed the presence of a crystalline material. Overall, it can be noticed that the prepared inorganic LDHs were less aggregated than MgAl-LDH functionalized with organic molecules (Figures 4 and S2)

Morphology of functional Ni.C with organic (DS) or inorganic parts $(\mathrm{Ru})$ is presented in Figure 5. Although some crystallinity of Ni.C-Ru LDH was confirmed by SAED, (Figure 5 b-inset), clear delimitation between crystalline parts (Ru metallic or oxide NCs or pellets) was difficult to be made.

Catalysis activity of inorganic LDH: Usually, in cinnamaldehyde hydrogenation the expected carbon-carbon double bond reduction is obtained together with $\mathrm{C}=\mathrm{O}$ reduction leading to alcohol formation. In our case, the use of Mg.C-Pd LDH catalysts afforded only the phenylpropionaldehyde, no alcohol was detected by GC/MS and a complete conversion was obtained in 12 hours under $0.1 \mathrm{MPa}$ of hydrogen at room temperature. On the contrary to Pd-LDH catalyst, Mg.C-Ru-LDH catalyst had a very different behavior in hydrogenation reaction. Expected to preferentially reduce the carbonyl group, as it happens classically, in this study only reducing the alkene, a yield of $43-$ $46 \%$ was obtained after 12 hours under $8 \mathrm{MPa}$ of hydrogen at room temperature. This unexpected reactivity and selectivity can be related to the difference in morphology and crystallinity level.

In conclusion, this work demonstrated for the first time the instant one-pot synthesis of functional LDHs using a new continuous configuration set-up working in hydrothermal conditions. The as prepared pristine or functional layered material corresponds with the standard LDH, showing high crystallinity. Moreover, an important feature is the very small LDH nanoparticles size obtained, with lateral dimension below $100 \mathrm{~nm}$ and thickness below $20 \mathrm{~nm}$, in only $5 \mathrm{~s}$. The concept was demonstrated with the preparation of i) pristine $\mathrm{LDH}$ by varying the cation $\left(\mathrm{Mg}^{2+}, \mathrm{Ni}^{2+}\right.$ or $\left.\mathrm{Zn}^{2+}\right)$ and the anion $\left(\mathrm{CO}_{3}{ }^{2-}, \mathrm{NO}_{3}{ }^{-}\right)$and ii) functional $\mathrm{LDH}$ by varying the functional agent, for example, long organic molecules (hybrid pillared $L D H$ ), enzymes (biohybrid $L D H$ ) and inorganic metal/oxide nanocrystals (inorganic-
$L D H)$. Moreover, high-quality and active materials were successfully synthesized, underlying the important contribution that this approach can bring, by opening new possibilities for designing and preparing a wide range of layered materials.

\section{Experimental Section}

LDH synthesis experimental details: The preparation method from the classical precipitation was transferred to a continuous hydrothermal approach, using a co-flow set-up (Figure S1), described in detail elsewhere. ${ }^{[12 e]}$ Briefly, for the preparation of pristine $L D H$, a room temperature aqueous solution of cationic salts $\left(\mathrm{M}\left(\mathrm{NO}_{3}\right)_{2}\right.$ $6 \mathrm{H}_{2} \mathrm{O}, \mathrm{M}=\mathrm{Mg}^{2+}, \mathrm{Ni}^{2+}$ or $\left.\mathrm{Zn}^{2+}+\mathrm{Al}\left(\mathrm{NO}_{3}\right)_{3} 9 \mathrm{H}_{2} \mathrm{O}\right)$ of $3.3 \times 10^{-2} \mathrm{M}$ (total concentration, with a cation $\mathrm{M}^{2+} / \mathrm{M}^{3+}$ molar ratio of 2) was mixed with a $\mathrm{NaOH}+\mathrm{Na}_{2} \mathrm{CO}_{3}\left(\mathrm{LDH}-\mathrm{CO}_{3}\right.$ type) preheated water solution $\left(3.3 \times 10^{-2} \mathrm{M}\right.$ and $0.55 \times 10^{-2} \mathrm{M}$, respectively) in a tubular reactor $(30 \mathrm{~cm}$ of length and $2.1 \mathrm{~mm}$ internal diameter) inside an oil bath. In the case of $\mathrm{LDH}-\mathrm{NO}_{3}$ type, only $\mathrm{NaOH}\left(3.3 \times 10^{-2} \mathrm{M}\right)$ was added in the base solution. The salts and base solutions were injected in the inner and external tubes (Figure S1), respectively, maintaining always a double flow rate for the base solution, in order to have $2 \mathrm{~mol}$ of $\mathrm{OH}^{-}$for $1 \mathrm{~mol}$ of cation. Depending on the temperature synthesis, the total flow rate was calculated for a residence time between 5 and $10 \mathrm{~s}$ and a pressure of $20 \mathrm{MPa}$ (Table S1). At the end of reaction (few seconds), the outlet solution containing the precipitated LDH was cooled with an ice bath and collected in a vessel. The material was centrifuged at $8000 \mathrm{rpm} /$ $20 \mathrm{~min}$ and washed twice with deionized water, followed by drying overnight at $80^{\circ} \mathrm{C}$. For TEM (JEOL 2100) and TEM-FEG HR (JEOL 2200FS) analyses, the LDH was kept as colloidal dispersion (gel in water) and drop casted on carbon grid, while for powder XRD (PANalytical X'Pert Pro with monochromatic wavelength of $\mathrm{Cu}$ Ka1), TGA and FTIR (Bruker-with absorption/ reflection measurements in the range of $7500 \mathrm{~cm}^{-1}-40 \mathrm{~cm}^{-1}$ ) the dried powder form was used. For the preparation of functional LDH, a similar procedure as described previously was used, with the difference that: 1) for in situ metal NPs deposition (labelled LDH-NPs), the salt solution contained additionally the metal salt precursor $\left(\mathrm{Pd}\left(\mathrm{NO}_{3}\right)_{2}\right.$ or $\mathrm{RuCl}_{3}$, with the molar ratio of $\mathrm{Mg}$ to $\mathrm{Pd}$ or Ru of 8); 2) for intercalation of organic anions (sodium dodecyl sulfate, SDS), labelled LDH$\mathrm{DS}$, to the base solution containing only $\mathrm{NaOH}$, DS of $0.55 \times 10^{-2} \mathrm{M}$ was added; 3) for enzyme transketolase (TK) functionalization (labelled LDH-TK), a third water solution containing the TK was injected in the middle of the reactor $(\mathrm{pH}$ of 7-9) in order to have a weight ratio of TK to LDH of 1.25. TK immobilization and enzymatic activity were determined as previously reported. ${ }^{[15 c]}$ To perform catalytic test of inorganic LDH, the autoclave was charged with $\mathrm{Mg}_{2} \mathrm{Al}-\mathrm{CO}_{3}-\mathrm{Pd}(5 \mathrm{mg})$, trans-cinnamaldehyde $(126 \mu \mathrm{L}, 1 \mathrm{mmol})$ and $\mathrm{EtOH}(2 \mathrm{~mL})$. Air was evacuated and replace with hydrogen adjusting the system to the desired pressure. The reaction mixture was stirred during 12 hours at room temperature. The crude reaction was filtered over silica, concentrated under vacuum affording pure 3-phenylpropionaldehyde in quantitative yield. No impurities were detected in GC/MS and NMR.

\section{Acknowledgements}

This work was supported by the Aquitaine region and the ANR-12-CDII-010-NANOCAUSYS. 
Keywords: continuous approach - hybrid materials • hydrothermal synthesis - layered double hydroxides - one-pot multistep process

[1] a) W. Feitknecht, M. Gerber, Helvetica Chim. Acta 1942, 25, 106-131 b) K.-H. Goh, T.-T. Lim, Z. Dong, Water Res. 2008, 42, 1343-1368; c) C. Mousty, V. Prevot, Anal. Bioanal. Chem. 2013, 405, 3513-3525; d) C. De Hoyo, Appl. Clay Sci. 2007, 36, 103-121; e) J.-M. Oh, T. T. Biswick, J.-H. Choy, J. Mater. Chem. 2009, 19, 2553-2563.

[2] a) X. Long, J. Li, S. Xiao, K. Yan, Z. Wang, H. Chen, S. Yang, Angew. Chem. Int. Ed. 2014, 53, 7584-7588; Angew. Chem. 2014, 126, 7714-7718 b) S. He, Z. An, M. Wei, D. G. Evans, X. Duan, Chem. Commun. 2013, 49, 5912-5920; c) D. Tichit, C. Gèrardin, R. Durant, B. Coq, Top. Catal. 2006 39, 89-96; d) L. Lin, L. Dou, H. Zhang, Nanoscale 2014, 6, 3753-3763; e) M. Zhang, Q. Yao, W. Guan, C. Lu, J.-M. Lin, J. Phys. Chem. C 2014, 118, $10441-10447$.

[3] a) C. Mousty, O. Kaftan, V. Prevot, C. Forano, Sens. Actuators B 2008, 133, 442-448; b) E. Scavetta, A. Casagrande, I. Gualandi, D. Tonelli, J. Elec troanal. Chem. 2014, 722-723, 15-22; c) J. Gong, Z. Guan, D. Song, Biosens. Bioelectron. 2013, 39, 320-323.

[4] E. D. Isaacs-Paez, R. Leyva-Ramos, A. Jacobo-Azuara, J. M. Martinez-Rosales, J. V. Flores-Cano, Chem. Eng. J. 2014, 245, 248-257.

[5] a) M. Shao, F. Ning, J. Zhao, M. Wei, D. G. Evans, X. Duan, J. Am. Chem. Soc. 2012, 134, 1071-1077; b) B. Kutlu, P. Schröttner, A. Leuteritz, R. Boldt, E. Jacobs, G. Heinrich, Mater. Sci. Eng. C 2014, 41, 8-16; c) L. Li, W. Gu, J. Chen, W. Chen, Z. P. Xu, Biomaterials 2014, 35, 3331-3339; d) L. Yan, W. Chen, X. Zhu, L. Huang, Z. Wang, G. Zhu, V. A. L. Roy, K. N. Yu, X. Chen, Chem. Commun. 2013, 49, 10938-10940; e) L. Jin, D. He, Z. Li, M. Wei, Mater. Lett. 2012, 77, 67-70.

[6] a) S. Yoon, J. Moon, S. Bae, X. Duan, E. P. Giannelis, P. M. Monteiro, Mater. Chem. Phys. 2014, 145, 376-386; b) P. Duan, W. Chei, J. Ma, Z. Shui, Construction Building Mater. 2013, 48, 601-609.

[7] a) M. Gong, Y. Li, H. Zhang, B. Zhang, W. Zhou, J. Feng, H. Wang, Y. Liang, Z. Fan, J. Liu, H. Dai, Energy Environ. Sci. 2014, 7, 2025-2032; b) R. Ma, X. Liu, J. Liang, Y. Bando, T. Sasaki, Adv. Mater. 2014, 26, $4173-$ 4178 ; c) H. Chen, L. Hu, M. Chen, Y. Yan, L. Wu, Adv. Funct. Mater. 2014, 24, 934-942.

[8] G. Abellán, E. Coronado, C. Marti-Gastaldo, A. Ribera, J. L. Jordá, H. García, Adv. Mater. 2014, 26, 4156-4162.

[9] a) V. Prevot, C. Forano, J. P. Besse, Chem. Mater. 2005, 17, 6695-6701; b) G. Abellán, J. A. Carrasco, E. Coronado, J. Romero, M. Varela, J. Mater. Chem. C 2014, 2, 3723-3731; c) Y. Yang, X. Zhao, Y. Zhu, F. Zhang, Chem. Mater. 2012, 24, 81-87; d) D.-Y. Wang, F. R. Costa, A. Vyalikh, A. Leuteritz, U. Scheler, D. Jehnichen, U. Wagenknecht, L. Häussler, G. Heinrich, Chem. Mater. 2009, 21, 4490-4497; e) Y. Kuroda, Y. Miyamoto, M Hibino, K. Yamaguchi, N. Mizuno, Chem. Mater. 2013, 25, 2291-2296 f) Y. Zhao, F. Li, R. Zhang, D. G. Evans, X. Duan, Chem. Mater. 2002, 14, 4286 ; g) Z. P. Xu, G. S. Stevenson, C. Q. Lu, G. Q. M. Lu, P. F. Bartlett, P. P. Gray, J. Am. Chem. Soc. 2006, 128, 36-37; h) G. Layrac, M. Destarac, C.
Gérardin, D. Tichit, Langmuir 2014, 30,9663-9671; i) S. Naito, K. Nitoh A. Ayral, M. Ogawa, Ind. Eng. Chem. Res. 2012, 51, 14414-14418; j) Y. Tokudome, T. Morimoto, N. Tarutani, P. D. Vaz, C. D. Nunes, V. Prevot, G. Stenning, M. Takahashi, ACS Nano 2016, 10, 5550-5559.

[10] a) B. Ballarin, A. Mignani, E. Scavetta, M. Giorgetti, D. Tonelli, E. Boanini, C. Mousty, V. Prevot, Langmuir 2012, 28, 15065-15074; b) P. Beaudot M. E. De Roy, J. P. Besse, J. Solid State Chem. 2004, 177, $2691-2698$; c) L. Sicard, S. Ammar, F. Herbst, C. Mangeney, F. Fievet, G. Viau, Mater. Res. Bull. 2009, 44, 1692-1699; d) M.-Q. Zhao, Q. Zhang, W. Zhang, J.-Q. Huang, Y. Zhang, D. S. Su, F. Wie, J. Am. Chem. Soc. 2010, 132, 1473914741.

[11] a) S. Abelló, J. Pérez-Ramírez, Adv. Mater. 2006, 18, 2436-2439; b) Q. Wang, S. V. Y. Tang, E. Lester, D. O'Hare, Nanoscale 2013, 5, 114-117; c) H. Liang, F. Meng, M. Caban-Acevedo, L. Li, A. Forticaux, L. Xiu, Z. Wang, S. Jin, Nano Lett. 2015, 15, $1421-1427$.

[12] a) S. Marre, C. Aymonier, P. Subra, E. Mignard, Appl. Phys. Lett. 2009, 95, 134105 ; b) Y. Roig, S. Marre, T. Cardinal, C. Aymonier, Angew. Chem. Int. Ed. 2011, 50, 12071-12074; Angew. Chem. 2011, 123, 12277-12280 c) E. S. Ilin, S. Marre, V. Jubera, C. Aymonier, J. Mater. Chem. C 2013, 1, 5058-5065; d) T. Gendrineau, S. Marre, M. Vaultier, M. Pucheault, C. Aymonier, Angew. Chem. Int. Ed. 2012, 51, 8525-8528; Angew. Chem. 2012, 124, 8653-8656; e) O. Pascu, L. Marciasini, S. Marre, M. Vaultier, M. Pucheault, C. Aymonier, Nanoscale 2013, 5, 12425-12431.

[13] a) J. Liu, J. Song, H. Xiao, L. Zhang, Y. Qin, D. Liu, W. Hou, N. Du, Powder Technol. 2014, 253, 41 -45; b) F. Cavani, F. Trifiro, A. Vaccari, Catal. Today $1991,11,173-301$

[14] Y. Zhou, X. Sun, K. Zhong, D. E. Evans, Y. Lin, X. Duan, Ind. Eng. Chem. Res. 2012, 51, 4215-4221.

[15] a) J. Abdoul-Zabar, I. Sorel, V. Helaine, F. Charmantray, T. Devamani, D. Yi, V. de Berardinis, D. Louis, P. Marlière, W.-D. Fessner, L. Hecquet, Adv. Synth. Catal. 2013, 355, 116-128; b) F. L. Theiss, G. A. Ayoko, R. L. Frost J. Therm. Anal. Calorim. 2013, 112, 649-657; c) G. Ali, T. Moreau, C. Forano, C. Mousty, V. Prevot, F. Charmantray, L. Hecquet, ChemCatChem 2015, 7, 3163-3170; d) M. Lorillière, M. De Sousa, F. Bruna, E. Heuson, T. Gefflaut, V. de Berardinis, T. Saravanan, D. Yi, W. D. Fessner, F. Charmantray, L. Hecquet, Green Chem. 2017, 19, 425-435.

[16] a) A. de Roy, C. Forano, J. P. Besse in Layered Double Hydroxides Present and Future (Ed.: V. Rives), NOVA Science Publisher, New York, 2001, pp. 1-39; b) V. A. Dritz, A. S. Bookin in Layered Double Hydroxides Present and Future (Ed.: V. Rives), NOVA Science Publisher, New York, 2001, pp. $40-100$.

[17] a) K. Benaissi, V. Hélaine, V. Prévot, C. Forano, L. Hecquet, Adv. Synth. Catal. 2011, 353, 1497-1509; b) N. Touisni, F. Charmantray, V. Helaine, C. Forano, L. Hecquet, C. Mousty, Colloids Surf. B 2013, 112, 452-459.

[18] O. Pascu, S. Moisan, J.-D. Marty, C. Aymonier, J. Phys. Chem. C 2014, 118, $14017-14025$. 